\title{
THE DOCTRINE OF PRIOR RESTRAINT
}

\author{
Thomas I. EMERSON*
}

The concept of prior restraint, roughly speaking, deals with official restrictions imposed upon speech or other forms of expression in advance of actual publication. Prior restraint is thus distinguished from subsequent punishment, which is a penalty imposed after the communication has been made as a punishment for having made it. Again speaking generally, a system of prior restraint would prevent communication from occurring at all; a system of subsequent punishment allows the communication but imposes a penalty after the event. Of course, the deterrent effect of a later penalty may operate to prevent a communication from ever being made. Nevertheless, for a variety of reasons, the impact upon freedom of expression may be quite different, depending upon whether the system of control is designed to block publication in advance or deter it by subsequent punishment.

In constitutional terms, the doctrine of prior restraint holds that the First Amendment forbids the Federal Government to impose any system of prior restraint, with certain limited exceptions, in any area of expression that is within the boundaries of that Amendment. By incorporating the First Amendment in the Fourteenth Amendment, the same limitations are applicable to the states.

Several features of the doctrine should be observed at the outset. In the first place, the doctrine deals with limitations of form rather than of substance. The issue is not whether the government may impose a particular restriction of substance in an area of public expression, such as forbidding obscenity in newspapers, but whether it may do so by a particular method, such as advance screening of newspaper copy. In other words, restrictions which could be validly imposed when enforced by subsequent punishment are, nevertheless, forbidden if attempted by prior restraint. The major considerations underlying the doctrine of prior restraint, therefore, are matters of administration, techniques of enforcement, methods of operation, and their effect upon the basic objectives of the First Amendment.

Moreover, the doctrine of prior restraint is, in some important respects, more precise in its application than most of the other concepts that have developed out of the First Amendment. It does not require the same degree of judicial balancing that the courts have held to be necessary in the use of the clear and present danger test, the rule against vagueness, the doctrine that a statute must be narrowly drawn, or the various formulae of reasonableness. Hence, it does not involve the same necessity for the court to pit its judgment on controversial matters of economics, politics, or social theory against that of the legislature. This is not to say that the

-A.B. 1928, LL.B. 193I, M.A. 1946, Yale University. Professor of Law, Yale University, since 1946. Author (with David Haber), Polimicai and Civil Rights in the United States (1952). Contributor to legal and other publications. 
doctrine of prior restraint is clear-cut, simple, and easy to apply. It is not. Further, it is subject to exceptions. But it does raise somewhat different problems, and ones perhaps more susceptible to judicial solution than those with which the Supreme Court appears to have been overwhelmed in dealing with other aspects of the First Amendment.

Despite an ancient and celebrated history, the doctrine of prior restraint remains today curiously confused and unformed. It has, moreover, been the object of considerable adverse criticism. When the doctrine was revitalized in Near v. Minnesota, ${ }^{1}$ one legal writer referred to it disparagingly as a "resurgence of the eighteenth century doctrine." In I949, another legal writer concluded, "Whatever the value of the prior restraints doctrine in the past, it has outlived its usefulness." Professor Freund has recently expressed the hope that "future cases will not be solved by a facile application of the subsequent-punishment-prior-restraint dichotomy." The doctrine has been largely or wholly rejected by several justices of the Supreme Court, past and present, though never by the whole Court. ${ }^{5}$

Nevertheless, the doctrine of prior restraint remains a part of our constitutional law and is assuming a special significance today. A number of crucial issues in civil liberties-issues which necessarily involve a decision on the status and scope of the doctrine-are likely to reach the Supreme Court in the near future. Among these is the right of state or local boards to censor motion pictures on obscenity grounds. Another is the censorship of comic books and similar literature.

But the doctrine of prior restraint has a more far-reaching importance. We are witnessing today a tremendous and ominous expansion of preventive law in the area of civil liberties. More and more, our controls are being devised not as punishment for actual wrongful conduct, but with a view to preventing future evils by a series of restrictions and qualifications that seriously jeopardize freedom of expression. The vast loyalty-security program is just such a system. So is the non-Communist oath of the Taft-Hartley Act, the registration and detention provisions of the Internal Security Act, and the operation of many legislative committees. Proposals for increased censorship are part of the same pattern. There are strong pressures in modern industrial society for controls over expression that prevent rather than punish after the event. In part, perhaps, the trend may be justified by the complexities of modern life and the increased need for effective regulation. But in part, the growth stems from the efforts of those who seek to manipulate the minds of large groups of citizens upon whom a government or administration must depend for support. In any event, against such a background the concept of prior restraint takes on a new and prominent significance.

\footnotetext{
${ }^{1}$ Sce infra pt. II.

${ }^{2}$ Note, Previous Restraints Upon Freedom of Speech, 3I CoLum. L. Riev. II 48 (I93I).

${ }^{3}$ Note, Prior Restraint-A Test of Invalidity in Free Speech Cases?, 49 Colum. L. Rev. I001, 1006 (r949).

*Freund, The Supreme Court and Civil Liberties, 4 VaNd. L. Rev. 533, 544 (1951).

Sec infra pt. IV.
} 
Surprisingly enough, the doctrine of prior restraint has never been thoroughly explored. There exists no comprehensive study of its historical roots, its application in judicial decisions, the basic considerations which underlie the principle, or its proper scope in a modern law of civil liberties. It is impossible, in this short sketch, to undertake an adequate study of the subject. The most that can be done here is to point out some of the highlights and to pose some of the questions. ${ }^{6}$

\section{I}

\section{Development of the Doctrine}

The doctrine of prior restraint grew out of the historical setting in which one of the early battles for freedom of expression was fought. The invention of printing in the fifteenth century and its rapid development in the sixteenth and seventeenth centuries opened vast possibilities for the communication of ideas in all fields of thought and action. Prevailing doctrines of spiritual and temporal sovereignty made it inevitable that control over the new medium of expression should be gathered firmly in the hands of the ruling authorities.

As early as $\mathrm{I}_{5} \mathrm{Or}$, Pope Alexander VI, in a bull which prohibited unlicensed printing, applied the technique of prior restraint as a means of control. In Englandthe immediate source of our doctrine of prior restraint-printing first developed under royal sponsorship and soon became a monopoly to be granted by the Crown. For almost two centuries, a stream of royal proclamations, Star Chamber decrees, and Parliamentary enactments, constantly increasing in complexity, shackled the art and the business of printing and publication.

The Licensing Act of $1662^{8}$ illustrates the scope of the system. Not only were seditious and heretical books and pamphlets prohibited, but no person was allowed to print any material unless it was first entered with the Stationers' Company, a government monopoly, and duly licensed by the appropriate state or clerical functionary. Further, no book was to be imported without a license; no person was permitted to sell books without a license; all printing presses had to be registered with the Stationers' Company; the number of master printers was limited to twenty, and these were to be licensed and to furnish bond; and sweeping powers to search for suspect printed matter in houses and shops, except the houses of peers, were granted. In this form, the licensing laws, renewed and augmented from time to time, continued through most of the latter half of the century.

\footnotetext{
${ }^{\circ}$ For discussion of the doctrine, in addition to the materials cited in notes 2.4 supra, sce Zecharian Chafee, Jr., Free Speech in the United States passim, esp. 9-30, 314-17, 375-81, 400-35, 521-23, 53240 (1941); C. Herman Pritchett, Civil Liberties and the Vinson Court c. 3 (1954); Note, Regulation of Comic Books, 68 HaRv. L. Rev. 489, 490-94 (1955).

'See 4 William Holosworth, A History of Exglish L.1w 360-79 (2d ed. 1937), and Press Control and Copyright in the 16 th and 17 th Centuries, 29 YAle L.J. 841 (1920); 2 JaMes Stephes, A History of the Criminal law of England 300-75 (1883); Clyde A. Duniway, The DevelopMent of Freedom of the Press in Massachusetts cc. 1-5 (1906); James Paterson, The Liberty of the Press, Speech, and Public Worship 43-52 (1880); Curtis Bok, Censorship and the Arts, in Civil Liberties Under Atrack ro7 (195i). Sce also material collected in Note, supra note 2 at iI58 ก. 8 .

${ }^{8}$ I3 \& I4 CAR. 2, c. 33.
} 
In 1695, when the current licensing law expired, the House of Commons declined to extend it. The House of Lords voted for renewal but, when the Commons insisted, acquiesced. Thus, the licensing system, in all important respects, lapsed. It was never revived. ${ }^{9}$

It is interesting to note that the demise of the licensing system appears to have occurred not so much because of broad opposition in principle to any curtailment of free expression, but rather because the system in operation had become generally unwieldy, extreme, and even ridiculous. Lord Macaulay summarizes the reasons given by the House of Commons to the House of Lords for refusing to renew the law: ${ }^{10}$

They pointed out concisely, clearly and forcibly, and sometimes with a grave irony which is not unbecoming, the absurdities and iniquities of the statute which was about to expire. But all their objections will be found to relate to matters of detail. On the great question of principle, on the question whether the liberty of unlicensed printing be, on the whole, a blessing or curse to society, not a word is said. The Licensing Act is condemned, not as a thing essentially evil, but on account of the petty grievances, the exactions, the jobs, the commercial restrictions, the domiciliary visits, which were incidental to it.

Furthermore, it is important to observe that, although the system of prior restraint was allowed to lapse, the law against seditious libel and blasphemy remained unaffected and was, indeed, applied with increasing frequency and severity as a form of subsequent punishment for expression considered hostile to state or church. ${ }^{\text {11 }}$

Developments in America paralleled, with some lag, the situation in England. By the second decade of the eighteenth century, the licensing laws had broken down. ${ }^{12}$

In the course of the eighteenth century, freedom of the press from licensing came to assume the status of a common law or natural right. Blackstone summarized the law in a famous passage: $:^{13}$

The liberty of the press is indeed essential to the nature of a free state; but this consists in laying no previous restraints upon publications, and not in freedom from censure for criminal matter when published. Every free man has an undoubted right to lay what sentiments he pleases before the public; to forbid this, is to destroy the freedom of the press; but if he publishes what is improper, mischievous or illegal, he must take the consequences of his own temerity.

Such was the situation when, in I79I, the First Amendment was drafted, adopted

${ }^{\circ}$ For a vivid account of the events leading to the refusal of the House of Commons to renew the licensing act, see 4 Thomas B. Macaulay, The History of England 430-43 (1879); and 5 id. 12-14. See also Holdsworth, supra note 7, 29 YALE L.J. at $852-56$.

${ }^{10}$ Macaulay, op. cit. supia note 9 , at 13.

${ }^{11}$ See E.J.C. Neep, Seditious Offenses 9-19 (1926); Chafee, supra note 16, c. 13; Hervey and Kelley, Some Constitutional Aspects of Statutory Regulation of Libels on Government, I5 Temp. L.Q. 453, 454-62 (1941); Shientag, From Seditiots Libel to Freedom of the Press, I I BrookLyN L. REv. $125(1942)$.

${ }_{12}^{2}$ See Duniwax, op. cit. supra note 7; Vance, Freedom of Speech and of the Press, 2 Minn. L. Rev. 239, 247 (1918).

13 4 BL. CoMMr. "I51-52. 
by Congress, and ratified by the states. The struggle over the licensing laws was certainly not forgotten. And there can be little doubt that the First Amendment was designed to foreclose in America the establishment of any system of prior restraint on the pattern of the English censorship system. Indeed, it was argued in some quarters that this was the sole purpose of the First Amendment and that, following Blackstone, it was not intended to embrace subsequent punishment of publications. ${ }^{14}$ Not until the twentieth century did the Supreme Court finally settle this issue in favor of the broader interpretation of the First Amendment. ${ }^{15}$ But the doctrine that no previous restraint of publication could stand against the First Amendment was never challenged. Thus, the concept was elevated to the status of constitutional principle.

\section{II}

\section{Near v. Minnesota}

For nearly I30 years after its adoption, the First Amendment received scant attention from the Supreme Court. Not until World War I brought an avalanche of prosecutions under the Espionage Act did the Court begin to explore the implications of the constitutional guarantee for freedom of expression. And it was some years later before the Court dealt at any length with the doctrine of prior restraint.

During this period of quiescence, there did arise a number of issues which might have called for consideration of the concept of prior restraint. But these problems either never reached the Supreme Court or were resolved on other grounds. ${ }^{16}$ Apart from occasional routine statements of principle, the Court did not invoke the doctrine until, in 193r, it decided the case of Near v. Minnesota. ${ }^{17}$

The statute before the Court in Near v. Minnesota was the so-called Minnesota Gag Law. Somewhat experimental in nature, this legislation had aroused considerable concern in the newspaper world. ${ }^{18}$ It provided that any person "engaged in the business" of regularly publishing or circulating an "obscene, lewd and lascivious" or a "malicious, scandalous and defamatory" newspaper or periodical "is guilty of a nuisance." Procedure was established for suit to be brought "in the name of the State to enjoin perpetually the persons committing or maintaining any such nuisance from further committing or maintaining it." The court issuing an injunction was empowered to punish disobedience, as in other cases of contempt, by a fine or jail sentence up to 12 months. ${ }^{19}$

\footnotetext{
${ }^{14}$ For discussion of the issue and collection of the materials, sce CHafeE, op. cit. stipra note 6, at 9-I2.

${ }^{15}$ Schenck v. United States, 249 U.S. 47 (I9r9), and later cases.

${ }^{10}$ The clearest use of prior restraint was in the postal laws and regulations, denying use of the mails under certain conditions. For discussion of this development, see Deutsch, Freedom of the Press and of the Mails, $36 \mathrm{MrCH}$. L. Rev. 703 (x938); Rogers, Federal Interference with Freedom of the Press, 23 YALE L.J. 559, 568-78 (I914); CHAFEE, op. cit. stupra note 6, at 42-51, 97-100, 298-305, 549-50; Donnelly, Government and Freedom of the Press, 54 ILI. L. Rev. 3I, 40-44 (1950); Milwaukec Publishing Co. v. Burleson, 255 U.S. 407 (1921). For other instances, see Note, supra note 2, at I151-55.

17283 U.S. 697 (1931).

${ }^{18}$ See L. T. Beman, Selected Articles on Censorship of Speech and the Press $211-18$ (1930).

${ }^{10} 283$ U.S. at $702-03$.
} 
The particular case involved the publishers of The Saturday Press, a weekly sheet issued in Minneapolis. After the publication of nine issues, suit was brought by the County Attorney alleging that the paper was "largely devoted to malicious, scandalous and defamatory articles" and seeking an injunction. No charge was made under the obscenity portion of the statute. The articles in question, as described by the Supreme Court with some understatement, "charged in substance that a Jewish gangster was in control of gambling, bootlegging and racketeering in Minneapolis, and that law enforcing officers and agencies were not energetically performing their duties." The state court, finding the publication constituted a "nuisance" within the statute, perpetually enjoined the defendants from issuing "any publication whatsoever which is a malicious, scandalous or defamatory newspaper, as defined by law."20

The Supreme Court held, five to four, that the statutory scheme constituted a prior restraint and hence was an abridgment of freedom of the press in violation of the First Amendment guarantees incorporated in the Fourteenth Amendment. Chief Justice Hughes, speaking for the majority, analyzed the operation of the statute and concluded it amounted to "an effective censorship." "... [T] in question does not deal with punishments," he said; "it provides for no punishment, except in case of contempt for violation of the court's order, but for suppression and injunction, that is, for restraint upon publication."21 The Chief Justice then traced the historical background of the First Amendment, stressing the intention of the framers to ban the English system of licensing the press. After pointing out that the prohibition against prior restraint did not apply in "exceptional cases"-noting as examples certain types of obstruction to the conduct of war, obscenity, and incitements to violence-the Chief Justice broadly laid down the doctrine in the following terms: $:^{22}$

The exceptional nature of its limitations places in a strong light the general conception that liberty of the press, historically considered and taken up by the Federal Constitution, has meant, principally although not exclusively, immunity from previous restraints or censorship.

The Chief Justice made no reference to the clear and present danger test or to other doctrines recently employed in cases of subsequent punishment. He expressly said, "In the present case, we have no occasion to inquire as to the permissible scope of subsequent punishment."23 And he made entirely clear that the doctrine of prior restraint protected the publication of material which could be the subject of subsequent punishment under criminal libel or other laws $:^{24}$

The fact that for approximately one hundred and fifty years there has been almost an entire absence of attempts to impose previous restraints upon publications relating to the malfeasance of public officers is significant of the deep-seated conviction that such restraints would violate constitutional right. Public officers, whose character and conduct
${ }^{20} \mathrm{Id}$. at $703-06$.
${ }^{21}$ Id. at 712,715 .
${ }^{22} I d$. at $7 \mathrm{I} 6$.
${ }^{23} \mathrm{Id}$. at 715 .
${ }^{24} I d$. at 718-19. 
remain open to debate and free discussion in the press, find their remedies for false accusations in actions under libel laws providing for redress and punishment, and not in proceedings to restrain the publication of newspapers and periodicals.

Justice Butler, writing for the four dissenters, characterized the decision as giving to freedom of the press "a meaning and a scope not heretofore recognized." His primary argument was that "the Minnesota statute does not operate as a previous restraint on publication within the proper meaning of that phrase." "It is fanciful to suggest," he said, "similarity between the granting or enforcement of the decree authorized by this statute to prevent further publication of malicious, scandalous and defamatory articles and the previous restraint upon the press by licensers as referred to by Blackstone and described in the history of the times to which he alludes."25

Near $v$. Minnesota is a landmark case. It remains to this day the major pronouncement of the Supreme Court on the doctrine of prior restraint. Two aspects of the decision deserve special attention:

In the first place, the Supreme Court, for the first time, vigorously and effectively enunciated the doctrine of prior restraint. It gave meaning and content to a concept which, until then, had never been clearly outlined. For the first time, also, the Court employed the doctrine to strike down a legislative act. In short, the Court in Near v. Minnesota, refurbishing an ancient principle, created a potent instrument of modern constitutional law.

A second important aspect of the decision lies in the Court's concept of prior restraint. There was, on the face of it, much to be said for the minority position. The Minnesota statute did not conform to the pattern of licensing of the seventeenth century variety. No original approval of a publication was required. Only after a person had published "malicious, scandalous and defamatory" matter could he be enjoined. And the injunction did not prevent him from continuing to publish at all; it only restrained him from publishing a "malicious, scandalous and defamatory" newspaper. ${ }^{26}$ Thus, the publisher would be guilty of contempt and punished only as and when he committed subsequent offenses. Theoretically, therefore, the statute could hardly be said to set up prior restraint. On paper, it was a system for subsequent punishment by contempt procedure.

But in practice, the system was bound to operate as a serious prior restraint. Punishment could be summarily dispensed by a single official, without jury trial or the other protections of criminal procedure, for infraction of a loose and illusive mandate. Under such circumstances, any publisher seeking to avoid prison would, in sheer self-protection, have to clear in advance any doubtful matter with the official wielding such direct, immediate, and unimpeded power to sentence. The judge would, in effect, become a censor.

Thus, the Court made clear that it was not interpreting the concept of prior

${ }_{25}$ Id. at $723,735-36$ (italics in original).

${ }^{28}$ Id. at 7 12-13. 
restraint on a narrow legalistic or historical basis. It was, as it said, testing the statute by its "operation and effect."

The Court, indeed, in applying the doctrine to a modern problem was raising many more questions than it answered. What, in fact, is prior restraint? What are the "exceptional cases" where it does not apply? What are the basic elements of the concept which should guide a Court in determining the scope of the doctrine? These issues require further analysis.

\section{III}

\section{The Nature of Prior Restraint}

In examining these problems, it is first necessary to define more precisely what forms of official restriction contain elements of prior restraint. We may then explore the characteristics of that mode of restriction and its impact upon freedom of expression.

As a starting point, one must assume the general principle that, under the First Amendment and our notions of a democratic society, freedom of expression is the rule and constraint the exception. It is not necessary to assume that the First Amendment imposes an absolute prohibition against governmental restriction upon public expression nor to accept the constitutional interpretation that gives the First Amendment a "preferred position" in the scale of constitutional values-although the author leans toward the first and fully agrees with the second. But the more commonly accepted principle, that only in the most urgent circumstances can a limitation upon freedom of expression be justified, and that the courts, under the First Amendment, have a serious obligation to strike down limitations which do not clearly meet such conditions, is fundamental to any analysis of prior restraint.

There is, at present, no common understanding as to what constitutes "prior restraint." The term is used loosely to embrace a variety of different situations. Upon analysis, certain broad categories seem to be discernible:

The clearest form of prior restraint arises in those situations where the government limitation, expressed in statute, regulation, or otherwise, undertakes to prevent future publication or other communication without advance approval of an executive official. Such limitations are normally enforced by criminal prosecution for having published without the required approval, the prosecution being based upon mere failure to obtain approval and not on any issue concerning the content or manner of the publication. Examples of this type of prior restraint are the English licensing laws, motion picture censorship, the requirement of permits for park meetings, and the like. In some cases, the method of enforcement may be refusal by the official to make available government facilities or services, such as in denial of the use of the mails.

A second form of prior restraint involves judicial officials and is based upon the injunction or similar judicial process, enforced through a contempt proceeding.

${ }^{27} I d$. at 708 . 
The injunction may be directed only against specific aspects of a particular kind of communication, as the injunction against publishing a "malicious, scandalous and defamatory newspaper" in Near v. Minnesota. Or it may attempt to prevent all communication entirely, as an injunction preventing publication of any further issues of a newspaper.

A third type of situation involves legislative restraints which make unlawful publication or other communication unless there has been previous compliance with specific conditions imposed by legislative act. In this situation, no approval of an executive or judicial official is involved. Examples of such restraint are those requiring registration of lobbyists or of certain political organizations. Laws imposing taxes on newspapers or other forms of communication may be said to fall within this category. Enforcement of the control is normally by criminal prosecution or other legal proceeding for failure to meet the condition.

Finally, there is a fourth type of situation which contains elements of prior restraint upon communication, but in which the restraint appears more indirect or secondary to some other immediate objective. This occurs, for example, where political views or other forms of expression are used as a test for holding an office or position of influence. Such restraints appear in the Taft-Hartley non-Communist affidavit and in the loyalty-security programs. Perhaps limitations upon picketing for a closed shop and the constraints flowing from the activities of legislative committees could be said to involve similar indirect or secondary restraints.

These various types of prior restraint-and perhaps others could be added-raise somewhat different issues. Furthermore, within each category, the type of communication concerned-whether it be books, newspapers, motion pictures, park meetings, or something else-naturally involves special considerations. For purposes of our analysis, we will consider primarily those characteristics of prior restraint which mark the most common forms of communications affected by the first, or executive, type of restraint. ${ }^{28}$

Breadth: A system of prior restraint normally brings within the complex of government machinery a far greater amount of communication than a system of subsequent punishment. It subjects to government scrutiny and approval all expression in the area controlled-the innocent and borderline as well as the offensive, the routine as well as the unusual. The machinery is geared to universal inspection, not to scrutiny in particular cases which are the subject of complaint or otherwise come to the attention of prosecuting officials. The pall of government

\footnotetext{
${ }^{28}$ The literature on the operation of systems of prior restraint is scattcred but voluminous. Among the more important is Anve Lyon Haight, Banved Books (1955); Chafee, op. cit. supra notc 6, and Governagent and Mass Communications esp. c. 3 (1947); Theodore Schroeder, "Odscene" Literature and Constitutional Law (igit); Morris L. Ernst and Alexander Lindey, Tue Censor Marches ON (1940); George R. Scott, Into Whose Hands (1945); Lockhart and McClure, Literature, The Law of Obsccnity and the Constitution, 38 Miss. L. Rev. 295 (1954); Note, Motion Pictures and the First Amendment, 60 Yale L.J. 696 (1951); Comment, Censorship of Obscene Literature By Informal Gou'crnmental Action, 22 U. CHI. L. REv. 216 (1954); Comment, Movie Censorship and the Supreme Court: What Next?, 42 CALIF. L. Rev. 122 (1954).
} 
control is, thus, likely to hang more pervasively over the area of communication, and more issues are likely to be resolved against free expression.

Timing and delay: Under a system of subsequent punishment, the communication has already been made before the government takes action; it thus takes its place, for whatever it may be worth, in the market place of ideas. Under a system of prior restraint, the communication, if banned, never reaches the market place at all. Or the communication may be withheld until the issue of its release is finally settled, at which time it may have become obsolete or unprofitable. Such a delay is particularly serious in certain areas-such as in motion pictures-where large investments may be involved. ${ }^{29}$

Propensity toward an adverse decision: A system of prior restraint is so constructed as to make it easier, and hence more likely, that in any particular case the government will rule adversely to free expression. A communication made is a fait accompli, and the publisher has all the practical advantages of that position. A government official thinks longer and harder before deciding to undertake the serious task of subsequent punishment-the expenditure of time, funds, energy, and personnel that will be necessary. Under a system of prior restraint, he can reach the result by a simple stroke of the pen. Thus, in one case, the burden of initial action falls upon the government; in the other, on the citizen. Again, once a communication has been made, the government official may give consideration to the stigma and the troubles a criminal prosecution forces upon the citizen. Before the communication has been issued, however, such factors would not enter the picture. For these and similar reasons, a decision to suppress in advance is usually more readily reached, on the same facts, than a decision to punish after the event.

Procedure: Under a system of prior restraint, the issue of whether a communication is to be suppressed or not is determined by an administrative rather than a criminal procedure. This means that the procedural protections built around the criminal prosecution-many of which are constitutional guarantees-are not applicable to a prior restraint. The presumption of innocence, the heavier burden of proof borne by the government, the stricter rules of evidence, the stronger objection to vagueness, the immeasurably tighter and more technical procedure-all these are not on the side of free expression when its fate is decided.

Further, the initial decision rests with a single government functionary rather than with a jury. Those who framed the First Amendment placed great emphasis upon the value of a jury of citizens in checking government efforts to limit freedom of expression. While the jury probably plays less of a role in this age of popular conformity, it, nevertheless, still continues to furnish an important safeguard against the abuses of officialdom. ${ }^{30}$

Finally, the net effect of using the administrative process is to place primary re-

${ }^{20}$ Note, for example, the delay in exhibiting the film which was the subject of litigation in Burstyn $v$. Wilson, 343 U.S. 495 (1952). See also ERNST AND LiNDEY, op. cit. stupra note 28, at 96.

${ }^{30}$ See, e.g., the failure of the prosecution of theater managers in Jersey City and Elizabeth, N.J., for showing the film, The Moon Is Blue. Comment, stpra note 28, 42 CaLIF. L. REv. at 126-27. 
sponsibility for judging the communication upon an executive official rather than in the courts. Judicial review of administrative action is limited in scope, tends to bow before administrative expertise, and is frequently unavailable in practice. Thus, sensitive issues of free expression are decided largely by a minor bureaucrat rather than through an institution designed to secure a somewhat more independent, objective, and liberal judgment. ${ }^{31}$

Opportunity for public appraisal and criticism: A system of prior restraint usually operates behind a screen of informality and partial concealment that seriously curtails opportunity for public appraisal and increases the chances of discrimination and other abuse. Decisions are less likely to be made in the glare of publicity that accompanies a subsequent punishment. The policies and actions of the licensing official do not as often come to public notice; the reasons for his action are less likely to be known or publicly debated; material for study and criticism are less readily available; and the whole apparatus of public scrutiny fails to play the role it normally does under a system of subsequent punishment. All this may have certain advantages from some points of view. In cases of alleged obscenity, for instance, publicity may serve to give much wider circulation to a publication ultimately condemned. And in some cases, individual citizens may not desire or benefit from greater publicity. In the long run, however, the preservation of civil liberties must rest upon an informed and active public opinion. Any device that draws a cloak over restrictions on free expression seriously undermines the democratic process. $^{32}$

The dynamics of prior restraint: Perhaps the most significant feature of systems of prior restraint is that they contain within themselves forces which drive irresistibly toward unintelligent, overzealous, and usually absurd administration. One factor is the ability and personality of the licenser or censor. As Milton long ago observed, ${ }^{33}$

If he be of such worth as behoves him, there cannor be a more tedious and unpleasing journey-work, a greater loss of time levied upon his head, than to be made the perpetual reader of unchosen books and pamphlets... we may easily foresee what kind of licensers we are to expect hereafter, either ignorant, imperious, and remiss, or basely pecuniary.

No adequate study seems to have been made of the psychology of licensers, censors, security officials, and their kind, but common experience is sufficient to show that their attitudes, drives, emotions, and impulses all tend to carry them to excesses. This is particularly true in the realm of obscenity, but it occurs in all areas where officials are driven by fear or other emotion to suppress free communication. ${ }^{34}$

\footnotetext{
${ }^{31}$ See the discussion in Lockhart and McClure, supra note 28, at 309-16, 388-90. Sce also Envst AND LINDEY, op. cit. stipra note 28 , at 215 .

${ }^{32}$ Note, for example, the reluctance of those seeking the ban of ccrtain paper-bound books, to bring the censorship into the open. Lockhart and McClure, supra note 28, at 309-16.

${ }^{33}$ Jolin Milton, AReopagitica 20-21 (Everyman cd., 1927).

3e See, e.g., ERnst and Lindley, op. cit. sipra note 28, at 217, 225-27; Heywood Broun AND Margaret Leech, Anthony Comstock 266, 273 (1927); Holbrook Jnekson, The Fear of Books 83-87, I84-85 (1932); Scort, op. cit. supra note 28, at 202-03; Pollock, The Censorship, 97 ForT-
} 
Further, it is necessary to keep in mind not only the character structure of the licenser, but the institutional framework in which he operates. The function of the censor is to censor. He has a professional interest in finding things to suppress. His career depends upon the record he makes. He is often acutely responsive to interests which demand suppression-interests which he himself represents-and not so well attuned to the more scattered and less aggressive forces which support free expression.

All this is true to some extent, of course, with regard to prosecutors who participate in the administration of systems of subsequent punishment. But such a prosecutor normally does not focus on a single problem in the way a licenser does. Nor does he wield comparable power. The long history of prior restraint reveals over and over again that the personal and institutional forces inherent in the system nearly always end in a stupid, unnecessary, and extreme suppression. ${ }^{35}$

Certainty and risk: It is frequently argued that a system of prior restraint affords individual citizens greater certainty in the law with less risk of serious consequences. Under such a system, it is said, an individual can find out what is permitted and what is forbidden without incurring the danger of criminal or similar sanctions in the event his interpretation of the law is erroneous. For this reason, some publishers prefer licensing systems to systems based on subsequent punishment. And this has been a factor in the establishment of private systems of censorship, such as exist in the motion picture industry and now in the comic book industry. From the point of view of some individuals, there is much to be said for these considerations. But from a public or social point of view-the interest of society as a whole in free expression-the argument is, in the long run, dubious. For it means, under most circumstances, less rather than more communication of ideas; it leaves out of account those bolder individuals who may wish to express their opinions and are willing to take some risk; and it implies a philosophy of willingness to conform to official opinion and a sluggishness or timidity in asserting rights that bodes ill for a spirited and healthy expression of unorthodox and unaccepted opinion.

Effectiveness: A system of prior restraint is, in general, more readily and effectively enforced than a system of subsequent punishment. Undoubtedly it is true that both systems depend ultimately upon the application of penal sanctions. But there are noteworthy differences. A penal proceeding to enforce a prior restraint normally involves only a limited and relatively simple issue-whether or not the communication was made without prior approval. The objection to the content or manner of the communication need not be demonstrated. And furthermore, the

Nightzy Rev. 880, 88I (igi2); James N. Rosenberg, Censorship in the United States 21 (1928); Alec Craig, The Banned Books of England 89 (1937).

${ }^{35}$ For examples see Macaulay, op. cit. supra note 9; Thomas May, The Constitutional History of ENGLaNd I02-06 (I863); Pollock, supra note 34, at 880-92; Lockhart and McClure, supra note 28, at 3i6-20; Morkis L. Ernst and William Seagle, To the Pure . . A Study of Obscenity and the CENSOR 38-56 (x928). 
violation of a censorship order strikes sharply at the status of the licenser, whose prestige thus becomes involved and whose power must be vindicated. Systems of subsequent punishment can, of course, be enforced to the hilt; but in practice, this rarely occurs or is limited to short periods of time. ${ }^{36}$

All in all, therefore, we must conclude that in a democratic society, such as ours, a system of prior restraint based upon executive approval will operate as a greater deterrent to free expression and cause graver damage to fundamental democratic rights than a system of subsequent punishment. This is, of course, not invariably so. A system of subsequent punishment, applying severe criminal sanctions in the first instance, may prove a greater obstruction to legitimate expression where ruthlessly enforced. This could be true particularly in a highly organized and repressive state. But in the looser confines of an open society, it will normally not be the case. For purposes of the judicial process-which would find it difficult to make refined distinctions between the operation of the two systems in each particular instance-this powerful tendency of prior restraint becomes a factor of critical and definitive importance.

These, then, are some of the considerations which underlie the doctrine of prior restraint. They are the reasons why the doctrine is not simply an arbitrary historical accident, but a rational principle of fundamental weight in the application of the First Amendment. All of them do not apply in every situation. And other factors, relating to the particular form of restraint and the particular area of communication, must obviously be taken into account. But they furnish the basic framework within which the doctrine of prior restraint must be judged.

The limits of this paper do not permit an analysis along the same lines of the other categories of prior restraint outlined above. Many of the same considerations apply, often to a lesser degree. But in those categories, too, the problem must be considered in the light of similar or comparable factors so far as they are applicable.

\section{IV}

\section{The Supreme Court's Treatment of Prior Restrainst}

In the years following Near v. Minnesota, the Supreme Court has frequently dealt with restrictions upon expression that have involved elements of prior restraint. There has developed some disagreement among the justices and some shifting in the attitude of the prevailing majority. Actually, the doctrine has never been subjected to thorough-going analysis, and no clear and full statement of principle has received acceptance of the Court.

Near $v$. Minnesota had raised, but left unsolved, the question of what exceptions, if any, existed to the general rule of no prior restraint. Chief Justice Hughes had indicated, by way of dictum, that the doctrine would not be applied in "exceptional cases." He mentioned three situations as illustrative of these exceptions. ${ }^{37}$ The first

${ }^{30}$ Sce, e.g., Report of the Select Committee on Current Pornographic Materials, H. R. Rep. No. 25ro, 82d Cong., 2d Sess. 5-12 (1952).

283 U.S. at $7 \times 6$. 
included restraints that could be imposed "[w] hen a nation is at war." The Chief Justice cited only the Schenck case ${ }^{38}$ - not a case of prior restraint-but went on to say: "No one would question but that a government might prevent actual obstruction to its recruiting service or the publication of the sailing dates of transports or the number and location of troops." The second exception related to obscenity: "On similar grounds, the primary requirements of decency may be enforced against obscene publications." Here he cited no authority. The third exception involved sedition: "The security of the community life may be protected against incitement to acts of violence and the overthrow by force of orderly government." In support of this third exception, the Chief Justice cited the Schenck case again and the Gompers case ${ }^{39}$-a case that appears to fall within the last category of prior restraint outlined above.

The war exception rests upon peculiar factors of obvious weight. But the Chief Justice made no attempt to explain why obscene or seditious utterances should be distinguished from "malicious, scandalous and defamatory" utterances. Certainly, no such distinction can be based upon the appeal to history; on the contrary, the opposition to licensing plainly extended to prior restraint of allegedly seditious publications and probably to the obscene, too, so far as obscenity was then a ground for restraint. Nor could the Court rely upon any modern authority. The entire passage remains obscure. It may be that the Chief Justice merely intended to make the traditional point that seditious and obscene publications were subject to subsequent punishment as exceptions to the First Amendment. In any event, the attempt to enumerate exceptions to the prior restraint rule was not carefully considered and can scarcely be said to have settled the issue.

We proceed, therefore, to a brief examination of the use of the prior restraint doctrine in the later cases. The problems are best presented by grouping the decisions according to the particular medium of expression. The limits of this paper do not permit an exploration of those situations, mostly falling within the fourth category above, which contain important elements of prior restraint but where the Supreme Court has not seriously attempted to apply the doctrine. Nor does it include several areas, such as post office censorship, control of radio and television, and the like, where the Court has not directly dealt with the issue. The major pronouncements of the Court fall within four areas-newspapers and books, distribution and canvassing, assembly in public places, and motion pictures. ${ }^{40}$

${ }^{38}$ Schenck v. United States, 249 U.S. 47 (1919).

${ }^{30}$ Gompers v. Bucks Stove \& Range Co., 22I U. S. 418 (I9II).

10 The only important decisions in other areas where the doctrine of prior restraint has played some part are Thornhill v. Alabama, 3 ro U.S. 88 (1940); and Hannegan v. Esquire, 327 U.S. I46 (1946). See also Donaldson v. Read Magazine, 333 U.S. 78 (1947); United States v. CIO, 335 U.S. I06, 153-55 (1948); Dennis v. United States, 34 I U.S. 494, 579 (195I). For discussion of some of these problems, see Donnelly, supra note I6; Kadin, Administrativc Censorship: A Study of the Mails, Motion Pictures and Radio Broadcasting, I9 B.U.L. REv. 533 (1939). A recent post office case raising the problem of prior restraint is Sunshine Book Co. v. Summerfield, 22 I F.2d 42 (D.C. Cir. 1954), cert. denied, 349 U.S. 921 (1955), 128 F. Supp. 564 (D.D.C. 1955). 


\section{Newspapers and Books}

Since the doctrine of prior restraint developed directly out of attempts to license the press, we should expect to find its application most clearly accepted in that area. Nothing in the growth of modern society has, thus far at least, appealed to the country as grounds for altering the considerations which led to the elimination of prior restraint upon the press. Actually, after Near v. Minnesota, no attempt to establish a licensing or censorship system for books or newspapers has come before the Supreme Court. Recently, efforts by local police officials to institute an informal system of censorship through threats of criminal prosecution for the sale of books placed on police or private lists have been outlawed in several courts. ${ }^{\mathbf{1 1}}$ In as much as these systems seem to embrace the worst evils of prior restraint, and since the press itself is involved, it may be expected that the Supreme Court would have little difficulty in disposing of cases of this nature.

The Supreme Court has dealt with one other ancient form of restraint upon the press-the imposition of a tax upon publication. In Grosjean v. American Press Co., ${ }^{42}$ the Court had before it a Louisiana statute, sponsored by Huey Long, which levied a license tax of two per cent upon the gross receipts of newspapers and periodicals having a circulation of over 20,000 a week. Justice Sutherland, writing for a unanimous Court, reviewed again the English licensing laws and discussed, in addition, the struggle in England and colonial America against "taxes on knowledge." He held that the Louisiana law had a "direct tendency to restrict circulation" and hence was clearly invalid as a form of prior restraint. ${ }^{43}$

The growth of the comic-book industry has been thought by some to raise new problems that demand for their solution some form of prior restraint. That the Supreme Court would consider the issues any different from the traditional ones seems highly doubtful. ${ }^{44}$

\section{Distribution and Canvassing}

The distribution of pamphlets or leaflets, either on the city streets or by door to door canvassing-also a traditional form of communication-has been increasingly subjected to various forms of municipal licensing. A series of these cases has been considered by the Supreme Court, most of them raised by the activities of Jehovah's Witnesses. In support of their ordinances, the municipalities have urged that licensing is justified in order to prevent public disorder, molestation of inhabitants, fraud, or littering of the city streets. With the exception of regulations aimed at canvassing for commercial purposes, the Supreme Court has consistently struck

\footnotetext{
${ }^{1}$ Bantam Books, Inc. v. Melko, 25 N.J. Super. 292, 96 A.2d 47 (Ch. 1953); New American Library v. Allen, II4 F. Supp. 823 (N.D. Ohio, 1953). But cf. Sunshine Book Co. v. McCaffrey, 112 N.Y.S.2d 476 (Sup. Ct. 1952). For a full discussion, see Comment, supra note 28, 22 U. CHI. L. Rev. 216. See also Note, supra note 6, 68 Harv. L. Rev. at 494-99.

12297 U.S. 233 (1936).

${ }^{13} I d$. at 244-45. Cf. Corona Daily Independent v. Corona, 115 Cal. App. 2d 382, 252 P. 2d 56, cert. denied, 346 U.S. 833 (r953).

${ }^{44}$ For discussion of the comic book problem, see Note, stipra note 6, 68 HARv. L. REv. 489 .
} 
down the ordinances. But the grounds for its decisions have not always been entirely clear.

In the first case, Lovell $\nu$. Griffin, ${ }^{45}$ the city ordinance prohibited the distribution of circulars or literature of any kind within the city limits without first obtaining written permission from the City Manager. Chief Justice Hughes, on behalf of a unanimous Court, held the ordinance void on its face: "... its character is such that it strikes at the very foundation of the freedom of the press by subjecting it to license and censorship." ${ }^{\text {"46 }}$ But the Chief Justice made some point of the fact that the ordinance was "not limited to 'literature' that is obscene or offensive to public morals or that advocates unlawful conduct"; and also that it was not limited "with respect to time or place" or "to ways which might be regarded as inconsistent with the maintenance of public order or as involving disorderly conduct, the molestation of the inhabitants, or the misuse or littering of the streets." implication that such limitations might have saved the ordinance.

This ambiguity was partially clarified by the decision in Schneider v. State.8 Here the ordinance specified that the Chief of Police "shall refuse a permit in all cases where the application, or further investigation made at the officer's discretion, shows that the canvasser is not of good character or is canvassing for a project not free from fraud." 49 The Court held the ordinance invalid as a prior restraint, Justice McReynolds dissenting. The majority opinion of Justice Roberts is not altogether clear. But it appears to accept the doctrine of prior restraint as prohibiting any form of advance permission. It expressly points out that frauds and trespasses "may be denounced as offenses and punished by law," that the time of canvassing can likewise be controlled, and adds: "Doubtless there are other features of such activities which may be regulated in the public interest without prior licensing or other invasion of constitutional liberty."

A third case reached the same result but opened the door to one form of restraint. In Cantwell v. Connecticut, ${ }^{51}$ the ordinance prohibited the solicitation of money or anything of value for a religious, charitable, or philanthropic cause unless the secretary of the public welfare council determined "whether such cause is a religious one or is a bona fide object of charity or philanthropy and conforms to reasonable standards of efficiency and integrity. ..."52 In its application to solicitation for religious purposes, the ordinance was held to be invalid as a prior restraint. Again, the opinion of Justice Roberts is not free from ambiguity. But it seems to say that no form of permit involving any discretion in the issuing officer would be sanctioned. On the other hand, it adds that a person wishing to solicit funds could

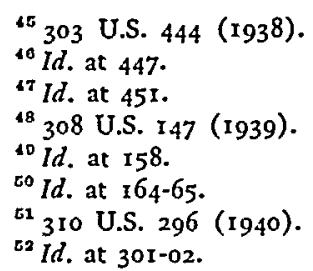


validly be required first "to establish his identity and his authority to act for the cause which he purports to represent." 53 Justice Roberts seems to be drawing a distinction between prior restraint involving executive permission and one imposing legislative conditions-that is, between the first and third types of prior restraint outlined above.

The Court has never departed from the position taken in the Schneider and Cantwell cases. ${ }^{54}$ But it has divided sharply upon the question whether a general licensing tax upon the solicitation of orders for merchandise could be applied to persons engaged in selling religious tracts. In Jones $v$. Opelika and Murdock $v$. Pennsylvania, ${ }^{55}$ the Court, by vote of five to four, struck down such taxes as constituting a form of prior restraint. These decisions were reaffirmed in Follett $v$. McCormick ${ }^{56}$ as to an occupational tax upon book agents living in the municipality, three justices dissenting. The issue in disagreement, however, was not whether a tax directed at reducing circulation of books or periodicals would constitute an invalid prior restraint, but whether a non-discriminatory tax upon all types of solicitation could be considered a restraint upon free expression.

Thus, in the distribution and canvassing cases the doctrine of prior restraint has remained substantially intact.

\section{Assembly in Public Places}

The series of cases dealing with prior restraint upon the right to assemble in public places has roused the sharpest controversy over the scope of the prior restraint doctrine. The decisions have related to three aspects of public assemblyparades, meetings on public streets or in public parks, and the use of sound trucks.

In this area of communication, a number of special factors must be considered. In the first place, the communication takes place upon public property. It has been argued that this fact gives the government wider scope in its choice of controls. Secondly, the facilities available-streets, parks, public buildings, and the like-are used for other purposes and, in any event, are limited in capacity. Hence, it is urged there is need for "traffic" regulation which can only be effectively secured by a permit system. Thirdly, the expression takes the form of public speech rather than the written word or private communication. From this, it is said, there arises a more difficult problem of maintaining public order and, therefore, greater need for preventive control. Finally, other factors may enter the picture, such as the effect upon others, including those who may not wish to listen, of loud noises from sound amplifiers.

In the case of parades, the "traffic" problem is clearly paramount. Obviously,

${ }^{5} I^{2}$. at 306.

U. Largent v. Texas, 318 U.S. 418 (1943); Thomas v. Collins, 323 U.S. $5 \times 6$ (1945), discussed infra; Marsh v. Alabama, 326 U.S. 501 (1946). See also Martin v. Struthers, 319 U.S. 141 (1943), invalidating a subsequent punishment ordinance. The Court's refusal to extend the doctrine to commercial solicitation was given expression in Breard v. Alexandria, 34 I U. S. 622 (195I), Justices Black and Douglas dissenting on First Amendment grounds. Id. at 649 .

${ }^{50} 319$ U.S. 103, 105 (1943).

50 32 I U.S. 573 (1944). 
advance preparations must be made and the right to use the streets for such purposes strictly limited. The Supreme Court, indeed, did not hesitate, in Cox v. New Hampshire, ${ }^{57}$ to uphold a system which required advance permission to stage a parade. The law was interpreted as giving authority to the licensing official to condition approval only upon the finding that "the convenience of the public in the use of the streets would not thereby be unduly disturbed, upon such conditions or changes in time, place and manner as would avoid disturbance."58 A "reasonable" license fee was also found acceptable. The Court was unanimous.

More difficult issues have arisen in cases where permits are required for meetings. The first case, Hague $v . \mathrm{ClO},{ }^{59}$ involved a Jersey City ordinance, administered by Mayor Hague, which required a permit for such a public assembly but authorized the Director of Public Safety to refuse it only "for the purpose of preventing riots, disturbances or disorderly assemblage." agree upon all aspects of the case, but seemed to be united upon the prior restraint issues. They held that the fact the meetings were to be conducted on public property did not authorize the city to refuse permission or subject them to unlimited control, and further, that the conditions designed to secure public order could not be enforced through a system of advance permission. Two justices dissented, and two did not participate.

In Thomas v. Collins, ${ }^{01}$ the Court went further and held that even a simple registration requirement, involving no executive discretion, could not be imposed as a condition to addressing a meeting for the purpose of encouraging labor organization and soliciting members. The prevailing opinion of Justice Rutledge, to which only Justices Black, Douglas, and Murphy agreed, indicated that such registration could be imposed upon the activity of soliciting members or funds, but could not be applied where speech was the predominant element. The opinion did not distinguish between prior restraint and subsequent punishment. Justice Jackson concurred separately, and Chief Justice Stone and Justices Roberts, Reed, and Frankfurter dissented.

Subsequent cases have left the prevailing situation cloudy. In Niemotko $v$. Maryland ${ }^{62}$ the municipality, by custom, required a permit before a meeting could be held in the city parks. No standards for granting or denying the permit were in effect. The Court unanimously held the system invalid as a prior restraint. But Chief Justice Vinson, writing the opinion, based the decision upon the "absence of narrowly drawn, reasonable, and definite standards for the officials to follow." He failed to make clear what kind of standards would have been sustained, whether only "traffic" control or broader conditions.

Kunz v. New York ${ }^{64}$ concerned a licensing system which required approval

c7 312 U.S. 569 (194I).

00307 U.S. 496 (1939).

02323 U.S. 516 (1945). The law was not confined to meetings in public places.

02340 U.S. 268 (195I).

04 340 U.S. 290 (I95I).

s8 Id. at 576

${ }^{60}$ Id. at 502 .

${ }^{\circ}$ Id. at 272 . 
from a city official to hold a religious meeting on public property. The ordinance contained no standards, but the permit was denied upon the ground that, in previous meetings, the speaker had ridiculed and denounced other religious beliefs. The Court held the law invalid as a prior restraint, again stressing that there were "no appropriate standards" to guide administrative action. Justice Jackson dissented in an opinion which contains the only serious effort of any member of the Court to appraise the doctrine of prior restraint. ${ }^{65}$ His conclusion was that the doctrine should not be applied in the field of street meetings. Justice Frankfurter, concurring in both the Niemotko and Kunz cases, made clear his position that existence of prior restraint was only one factor to be considered in First Amendment cases and not one that was decisive in itself. ${ }^{68}$

Poulos v. New Hampshire, ${ }^{67}$ the most recent of the decisions, failed to clarify the situation. Here, the statute imposing a license for public, open-air meetings was interpreted by the state court to require "uniform, non-discriminatory and consistent administration in the granting of licenses." ${ }^{88}$ The speaker was convicted for holding a meeting without a license after one had been improperly refused him. Justice Reed, writing for the majority, construed the statute as a "ministerial, police routine for adjusting the rights of citizens" and leaving to licensing officials "no discretion as to granting permits, no power to discriminate, no control over speech." ${ }^{100}$ Upon this dubious interpretation, he held that no prior restraint was involved and sustained the statute. He then went on to affirm the conviction on the ground that the speaker should have exhausted his state remedies for the wrongful refusal to issue the license. Both aspects of the decision, while not repudiating the doctrine of prior restraint in principle, seriously qualify it in practice.

Justice Frankfurter concurred in the Poulos decision without passing on the prior restraint issue. ${ }^{70}$ Justices Black and Douglas dissented on both issues. They read the statute as imposing an invalid prior restraint and, apart from that, would have held the speaker immune from punishment when a permit had been unlawfully refused. ${ }^{71}$

Finally, the sound truck cases should be briefly mentioned. In the first, Saia $v$. New York, ${ }^{72}$ the municipal ordinance forbade the use of sound amplifiers except by permission of the Chief of Police. A majority of five justices-Vinson, Black, Douglas, Murphy, and Rutledge-held the ordinance invalid as a prior restraint, noting that it contained no standards and was not "narrowly drawn to regulate the hours or places of use of loudspeakers, or the volume of sound." 73 The implication was that a system of prior restraint limited to "traffic" regulation and the control of sound would be upheld. Justices Reed, Frankfurter, Jackson, and Burton dissented.

But a few months later, in Kovacs v. Cooper, ${ }^{74}$ the Court dealt with another

\footnotetext{
is Id, at 295 .

${ }^{68} \mathrm{Id}$. at 402 .

${ }^{71}$ Id. at $421,422$.

${ }^{74} 336$ U.S. 77 (1949).
}

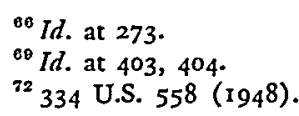


ordinance which made it unlawful to operate on the city streets a "sound amplifier ... or any instrument of any kind or character which emits therefrom loud and raucous noises." ${ }^{.75}$ No permit system was involved; the ordinance was enforceable solely by subsequent punishment. Chief Justice Vinson joined the dissenters in the Saia case to uphold the ordinance. Interestingly enough, Justice Reed, writing the prevailing opinion, distinguished the Saia case on the sole ground that the ordinance there involved a system of prior restraint, whereas the Kovacs ordinance established a system of subsequent punishment. It appears doubtful, however, that the decision turned upon that distinction.

The net result of the public assembly cases has been to strike down prior restraine in every case where it has been found to exist, except where it has been based upon "traffic" control. But the majority of the Court has probably not committed itself to such a strict application of the prior restraint doctrine. The language of some of its opinions indicates that it might allow systems of prior restraint to include conditions other than "traffic" control, provided the standards are clearly and precisely set forth. And its general attitude toward prior restraint, as evidenced by its unwillingness to find it in the Poulos case, indicates a somewhat grudging acquiescence in the doctrine.

Justice Frankfurter, and previously Justice Jackson, for all practical purposes abandoned the doctrine in public assembly cases. On the other hand, Justices Black and Douglas have maintained a firm position in support of the doctrine and its implications. They have shown no sign of admitting any exceptions other than the "traffic" controls and precise regulation of the volume of sound in the amplifier cases.

\section{Motion Pictures}

Official censorship systems for motion pictures, requiring advance approval before a film can be shown, represent what is probably the closest approach in America today to the English licensing laws of the seventeenth century. The machinery for control is strikingly similar. Obviously, censorship in this field is prior restraint in its classical form.

Until 1952, censorship of films could not be challenged on First Amendment grounds because the Mutual Film case ${ }^{76}$ had held that motion pictures were mere entertainment and not subject to the protection of that constitutional provision. The decision in Burstyn v. Wilson, ${ }^{77}$ however, overruled the Mutual Film case and brought motion pictures within the scope of the First Amendment. Consequently, the issue is now squarely posed whether the censorship systems are valid under the doctrine of prior restraint.

A basic issue-that such censorship does constitute prior restraint-was indeed

${ }^{75} \mathrm{Id}$. at 82. Justice Reed went on to make one of the most unqualified pronouncements on prior restraint in any Court opinion: "When ordinances undertake censorship of speech or religious practices before permitting their exercise, the Constitution forbids their enforcement." Ibid.

${ }^{76}$ Mutual Film Corp. v. Industrial Commission, 236 U.S. 230 (1915).

${ }^{7} 343$ U.S. 495 (1952). 
flatly decided in the Burstyn case. The law under which that case arose authorized the censor to deny a license to any film, which was "obscene, indecent, immoral, inhuman, sacrilegious, or is of such a character that its exhibition would tend to corrupt morals or incite to crime. ..."78 The particular film-The Miracle-was refused a license on the ground that it was "sacrilegious." Six members of the Supreme Court joined in an opinion by Justice Clark that the New York law constituted a system of prior restraint: $:^{79}$

The statute involved here does not seek to punish, as a past offense, speech or writing falling within the permissible scope of subsequent punishment. On the contrary, New York requires that permission to communicate ideas be obtained in advance from state officials who judge the content of the words and pictures sought to be communicated. This Court recognized many years ago that such a previous restraint is a form of infringement upon freedom of expression to be especially condemned.

The Court then went on to say that Near v. Minnesota recognized certain exceptions to the rule of no prior restraint and framed the issue in these terms: "In the light of the First Amendment's history and of the Near decision, the State has a heavy burden to demonstrate that the limitation challenged here presents such an exceptional case."so Addressing itself to this question, the Court held that a system of prior restraint based on the standard of "sacrilegious" did not constitute an exception and hence was invalid under the general rule. Thus, the Court made clear that the doctrine of prior restraint was, in general, applicable to the medium of motion pictures, but that particular standards of restraint might be considered exceptions.

From this point, the Court has proceeded cautiously. It rejected the standard of "sacrilegious" on two related grounds: first, the standard was so broad that "the censor is set adrift upon a boundless sea"; secondly, "the state has no legitimate interest in protecting any or all religions from views distasteful to them which is sufficient to justify prior restraints upon the expression of those views." 81 The Court expressly refrained from deciding the validity of other standards, including "whether a state may censor motion pictures under a clearly-drawn statute designed and applied to prevent the showing of obscene films." 82

Justices Reed, and Frankfurter and Jackson concurred in the decision, but not on prior restraint grounds. ${ }^{83}$ The first considered the film not "of a character that the First Amendment permits a state to exclude from public view."84 The two latter took the position that the standard was unduly vague and hence did not satisfy due process requirements.

In three subsequent cases, all decided per curiam without opinion, the Court has followed the same piece-meal approach. ${ }^{85}$ The effect of these decisions has been

\footnotetext{
is Id. at 497.

${ }^{8 x} I d$. at 504-05.

${ }^{7 \theta}$ Id. at 503.

${ }^{82}$ Id. at 506 .

${ }^{80} I d$. at 504 .

${ }^{84} \mathrm{Id}$. at 507 .

${ }^{83}$ Id. at 506,507 .

${ }^{85}$ Gelling v. Texas, 343 U.S. 960 (1952), citing the Burstyn case and Winters v. New York, 333 U.S. 507 (1948), a due process vagueness case (Justice Frankfurter concurred on the basis of the
} 
to hold invalid systems of prior restraint based upon standards of "prejudicial to the best interests of the people," "immoral," "sexually immoral," and "harmful" (apparently interpreted by the state court as "inciting to crime"). It is not clear that the Court would sustain any of these terms as standards for subsequent punishment, so the extent of its commitment to the doctrine of prior restraint remains ambiguous. But Justices Black and Douglas, in concurring opinions, have made plain their views that the doctrine of prior restraint should apply to all aspects of motion picture censorship. Justice Frankfurter continues to base his concurrence on vagueness grounds.

The major problem remaining, so far as the majority is concerned, is the one expressly bypassed in the Burstyn case-whether a system of prior restraint may be based upon the standard of "obscene" or some comparable term. It will be remembered that one of the exceptions mentioned in Near v. Minnesota was the case of "obscene publications." Yet, it hardly seems likely today that the Court would sanction a censorship of newspapers or books based upon an exception for obscenity. To sustain such an exception for motion pictures, therefore, would require the Court to find novel or distinguishing features in that medium of expression.

On balance, it is doubtful that such features exist. It may be urged that motion pictures reach a larger audience, that they convey a pictorial impression instead of a verbal one, or that they are largely designed for entertainment purposes. The last suggestion seems definitely disposed of by the Burstyn decision; and the two former scarcely seem sufficient to overcome-in fact they tend to reinforce-the considerations which underlie the doctrine of prior restraint. Furthermore, there is strong ground for believing that motion pictures are, by virtue of the economics of the industry, more susceptible to the dangers of prior restraint than most other media of communication. It may be suggested also that motion pictures, normally exhibited before vast audiences, are readily controlled by systems of subsequent punishment, so that no prior restraint is needed to accomplish any lawful regulation. ${ }^{86}$

In any event, the decision of the Supreme Court on this point will be a crucial one for the doctrine of prior restraint. Almost certainly it will force the Court to make a closer analysis of the doctrine and its implications. It may result in a clarification of the Court's position which could reaffirm the doctrine as a major constitutional principle or reduce it to virtual impotence.

Winters case only); Superior Films v. Dep't of Education and Commercial Pictures v. Regents, 346 U.S. 587 (1954), citing only the Burstyn case.

${ }^{80}$ For a discussion of motion picture censorship, see Note, supra note 28, 60 YALE L.J. 696; Comment, supra note 28, 42 CaLIF. L. Rev. 122; Kupferman and O'Brien, Motion Picture Censorship-The Memphis Blues, 36 CoRnelz L.Q. 273 (195I); Comment, Prior Restraints on Motion Pictures, 4 Catmolte U.L. Rev. XI2 (1954); Desmond, Censoring the Movies, 29 Notre Dame Law. 27 (1953). Sec also American Civil Libcrties Union v, Chicago, 3 Ill. 2d 334, I2I N.E.2d 585 (1954) (upholding power of the City of Chicago to censor motion pictures on obscenity grounds), appeal dismissed for want of a final judgment, 348 U. S. 979 (1955); RKO Radio Pictures v. Dep't of Education, I62 Ohio St. 263, 122 N.E.2d 769 (1954) (majority of four declaring Ohio censorship law unconstitutional, but law still valid as six votes are required for a holding of unconstitutionality). 


\section{CoNCLUSION}

The doctrine of prior restraint, while growing out of historical circumstances, finds its rationale today in the grievous impact which systems of prior restraint exert upon freedom of expression. The form and dynamics of such systems tend strongly towards over-control-towards an excess of order and an insufficiency of liberty. The doctrine does not require a choice between regulation or no regulation. It simply forbids a particular method of control which experience has taught tends to create a potent and unnecessary mechanism of government that can smother free communication. These tendencies in systems of prior restraint are even more dangerous today in view of the growing pressures for preventive controls over many forms of expression. Thus, the perils that presently threaten democratic rights in this country confirm the basic soundness of the rule against prior restraint.

The application of the doctrine to various forms of prior restraint and to various areas of communication raise some difficult problems. In general, it is clear that the most serious form is that which entrusts the prevention of communication to an executive official. Around this type of restraint, the worst evils of the system are likely to accumulate. There seems to be no reason why the rule against prior restraint in this form should not apply in all areas of expression. Such, indeed, has been the import of the Supreme Court decisions since Near v. Minnesota.

The question is then presented whether it is advisable to recognize any exceptions to the general rule as applied to executive restraint. Two exceptions seem clearly indicated. One is the exception for prior restraint necessary to military operations in time of war. So long as this exception is confined to periods of actual hostilities, it is perhaps not a matter of great significance. In the next war, the issue of prior restraint is likely to be overshadowed by other problems. The exception could prove dangerous, however, if it is applied to defensive or preparatory operations. In this application, it should be strictly limited.

A second exception consists in those "traffic" controls necessary to regulate communication where facilities are limited. Such controls involve, primarily or entirely, matters of time and place. To be effective, they usually must be applied in advance. Furthermore, these controls can be administered through precise and almost automatic rules which leave little or no discretion to an executive official. In view of these considerations, an exception based upon "traffic" controls would normally seem justified.

Beyond this, there may be occasional controls that can safely be handled through prior restraint. One such may be the volume of sound in the use of amplifying equipment. Such a control likewise can be expressed in definite, or even quantitative, terms. Yet, even here, it is doubtful that necessary limitations could not be achieved through a system of subsequent punishment.

In any event, exceptions beyond these limited categories are dangerous and tend 
to nullify the doctrine. Standards relating to public order in public assembly cases and standards based upon such concepts as obscenity, for instance, cannot be reduced to precise form. They inevitably leave in the hands of the administrator a wide and largely uncontrolled discretion. And once such exceptions are admitted, they give the executive official a jurisdiction and status to inspect and limit communication. Thus, they introduce all the evils the rule against prior restraint was intended to eliminate. As to those that have thus far been proposed, it is hard to see why the problems for which a remedy is sought cannot also be handled effectively by methods of subsequent punishment.

As to the judicial form of prior restraint, similar considerations apply. Where the injunction or other judicial process prohibits only certain kinds of communication, as in Near v. Minnesota, the judicial officer tends to be in the same position as an executive officer. Where the injunction prohibits all communication, the element of individual control is eliminated or minimized, but the restraint includes lawful as well as unlawful communication. In either case, the restraint is pervasive and should normally fall within the rule.

In the legislative form of prior restraint, somewhat different factors pertain. Here no individual discretion is involved. The control may operate to prevent expression, but most of the abuses arising out of intimate government inspection and supervision of communication are absent. Under such circumstances, the strict rule of prior restraint should not apply. Hence, the validity under the First Amendment turns upon the same sort of considerations as in subsequent punishment cases, with the element of preventive control operating as an additional, but not conclusive, factor. The same considerations apply to those situations in the fourth category, where elements of prior restraint exist, but the restraint is indirect or secondary.

$\mathrm{Up}$ to the present time, in their results at least, the decisions of the Supreme Court are consistent with the foregoing principles. But the majority of the Court has never formulated them in a comprehensive way and occasionally, as in the Poulos case, has not reached, in practice, results consonant with the theory. Justice Frankfurter has rejected the theory in important areas. Only Justices Black and Douglas have fully adopted the doctrine in principle and practice.

Unless the doctrine of prior restraint is given a more rational and comprehensive form, it is likely to be whittled away in future decisions. It is to be hoped that in the cases likely to be presented soon, the Court will resolve the present ambiguity and wholeheartedly accept the doctrine. 